\title{
Evaluation of trophic level of the largest dimictic lakes of western Pomerania based on the Carlson criteria
}

\author{
Jacek Kubiak, Sylwia Machula, Katarzyna Stepanowska, Marcin Biernaczyk \\ Department of Hydrochemistry and Aquatic Biological Resources, West Pomeranian University of Technology in Szczecin, \\ Kazimierza Królewicza 4, 71-550 Szczecin, Poland; e-mail: jacek.kubiak@zut.edu.pl
}

\begin{abstract}
Between the years 1970-2010, using the Carlson model criteria, the rate of eutrophication and trophic level of the largest dimictic lakes of Western Pomerania were studied. It was found that during the testing period, Lake Ińsko Duże was a mesotrophic reservoir, and Lakes Wądół, Będzin and Ińsko Małe were characterized by a highly advanced eutrophy. Lakes Woświn, Morzycko, Krzemień, Chłop Duży and Jelenin had borderline characteristics between being mesotrophic and eutrophic, while Lakes Narost, Chłop Mały and Wisala were typically eutrophic reservoirs. During the study, changes in the trophic level of Lakes Ińsko Duże and Morzycko and Woświn were noted. The first of the reservoirs listed had the best water quality in the second half of the 1990s, during which time the other two lakes had the worst water quality, taking into account the whole study period. Such changes were not observed in the other reservoirs examined.
\end{abstract}

Key words: eutrophication, trophic level, Carlson Criteria, Western Pomeranian lakes

\section{Introduction}

In the context of the complex problem of environmental pollution, great importance is attributed to the process of over-fertilization of surface waters, with eutrophication being a very important issue in their protection. Urbanization, industrialization and intensive agricultural production in the catchment area, as well as a significant development of tourism, with a lack of effective methods of protecting the lakes, affect them negatively and increase loading of biogenic substances, especially phosphorus and nitrogen. This condition resulted in recent decades in the rapid eutrophication of lakes, and loads of biogenic elements are often above the levels considered by Vollenweider (1989) to be dangerous. The high rate of eutrophication and high trophic level of surface waters, especially lakes, have become a global problem. The changes negatively impacting human life, and at the same time brought about by mankind, escalated in the 1930s, and now in many countries, including Poland, have grown to a dangerous size. The ongoing process of eutrophi- cation has led, and continues to lead, to a decrease in the quality and disturbances in the biocenotic balance of the waters, and is visible even in the water bodies under special protection: in national parks.

Anthropopressure makes the abiotic factors, subject to quick changes, have a decisive impact on the functioning of hydrobiocenoses. The process has been reinforced in surface waters due to urbanization and intensive development of industry and agriculture. As a consequence, in the West Pomeranian Lake District, as in other Polish regions, the surface waters have been going through the process of eutrophication, constituting an extremely important problem in their protection, particularly in relation to lakes $(\mathrm{Ku}-$ biak 2003).

The increase in trophic level of lakes causes a decrease in their value in use: reducing the environmental values of lakes, their tourist and recreational attractiveness, as well as the possibility of their usage for fishing (Vollenweider 1971; Lossow 1995; Kalff 2002; Kubiak 2003). This results in measurable economic losses. It is also considered that eutrophication 
is the greatest threat to the biodiversity of freshwater habitats (Hillbricht-Ilkowska 1998). The economic importance of the lakes and the need to protect them are undisputed. In Poland, too, the escalation of the process of eutrophication has been observed (Kubiak 2003).

Lakes are particularly sensitive to contaminants; they often do not return to their original state even after elimination of the source of contamination. Protection and restoration of lakes, especially those degraded, is extremely difficult and requires removal of the causes of degradation and knowledge of the complex ecosystem of the lake, the right choice of methods of restoration, and a consistent, often longterm study (Lossow 1995; Choiński and Ptak 2009) of their effectiveness. The costs of these works must be borne to prevent the degradation of lakes (Lossow 1995). Putting in order the wastewater management, and changes in soil use in the lake catchment areas are just two of the ways to protect lakes, which can improve the quality of their waters.

Given the economic importance of lakes, the need to protect them, and the impact of eutrophication on the water quality in these reservoirs, in the present study the eutrophic levels and their changes in the years 1970-2010 in the largest (over 100 ha) stratified lakes of Western Pomerania have been presented.

\section{Materials and Methods}

The study covered the greatest (of a surface area larger than 100 ha) dimictic lakes in Western Pomerania located in the following areas:

- Ińskie Lake District in the catchment of the upper River Ina, ie. Lakes Ińsko Duże, Wisala, Ińsko Małe (Odnoga Linowska) and Krzemień;

- Myśliborskie Lake District, in the western part, Lakes Morzycko, Narost and Jelenin and in the eastern part, situated in the catchment of the River Myśla, Lakes Wądół (Lipiańskie Północne), Będzin, Chłop Wielki and Chłop Mały.

- Also Lake Woświn, in the catchment area of the River Rega, north of the Ińskie Lake District and Lake Miedwie, located in the Stargard Plains, have been included in the research.

In the present study, the results of the authors' own research as well as materials from the Department of Hydrochemistry and Water Protection of the West Pomeranian University of Technology in Szczecin have been used. Some of the earlier results for Lakes Morzycko, Będzin and Wądół were collected from the materials of the State Inspectorate for Environmental Protection (OBiKŚ 1977). The geographical position of the lakes studied and selected morphometric indicators of their basins are given in Table 1 .

Table 1. Geographical position and selected morphometric indicators of the lakes studied

\begin{tabular}{|c|c|c|c|c|c|c|c|c|c|c|c|c|}
\hline Lake & Będzin & Chłop & $\begin{array}{l}\text { lńsko } \\
\text { Duże }\end{array}$ & Ińsko Małe & Jelenin & Krzemień & Miedwie & Morzycko & Narost & Wądół & Wisala & Woświn \\
\hline \multicolumn{13}{|l|}{ Location: } \\
\hline Latitude $\left[^{\circ}\right]:$ & 52.984 & 53.000 & 53.444 & 53.432 & 52.910 & 53.376 & 53.268 & 52.862 & 52.882 & 53.008 & 53.415 & 53.525 \\
\hline Longitude [ $\left.{ }^{\circ}\right]$ : & 14.941 & 14.900 & 15.554 & 15.514 & 14.446 & 15.554 & 14.883 & 14.410 & 14.505 & 14.955 & 15.555 & 15.412 \\
\hline Elevation above sea level [m]: & 59.7 & 60.1 & 127.0 & 127.0 & 71.0 & 91.7 & 13.0 & 51.4 & 59.0 & 61.4 & 112.2 & 78.9 \\
\hline \multicolumn{13}{|l|}{ Shape: } \\
\hline Maximum length [m]: & 3135 & 3800 & 5400 & 2950 & 2500 & 3510 & 16200 & 2900 & 2525 & 3015 & 3415 & 9500 \\
\hline Maximum width [m]: & 710 & 1125 & 2100 & 725 & 1400 & 1030 & 3160 & 2400 & 625 & 755 & 940 & 2000 \\
\hline Average width [m]: & 445 & 860 & 901 & 345 & 417 & 653 & 2177 & 1182 & 427 & 512 & 531 & 852 \\
\hline The length of coastline [m]: & 8250 & 16850 & 31450 & 7600 & 7375 & 8300 & 38800 & 12025 & 6600 & 11850 & 12112 & 26075 \\
\hline \multicolumn{13}{|l|}{ Surface: } \\
\hline total catchment area $\left[\mathrm{km}^{2}\right]$ & 206.1 & 28.8 & 40.6 & 9.8 & 14.3 & 85.0 & 10117 & 66.0 & 23.6 & 7.1 & 53.4 & 56.3 \\
\hline immediate catchment area $\left[\mathrm{km}^{2}\right]$ & 5.4 & 8.8 & 15.9 & 6.8 & 14.3 & 11.4 & 570 & 9.81 & 8.5 & 7.1 & 7.81 & 31.8 \\
\hline water surface [ha] & 139.6 & 326.7 & 486.6 & 101.8 & 104.3 & 229.1 & 35270 & 342.7 & 107.9 & 154.5 & 181.5 & 809.1 \\
\hline \multicolumn{13}{|l|}{ Depth: } \\
\hline maximum [m] & 15.4 & 32.9 & 41.7 & 11.7 & 21.4 & 29.2 & 43.8 & 60 & 13.2 & 15.9 & 15.4 & 28.1 \\
\hline Average [volume/surf. of w. table] & 4.5 & 10.7 & 12.9 & 5.9 & 8.8 & 9.6 & 19.3 & 14.5 & 6.3 & 5.3 & 5.9 & 9.4 \\
\hline \multicolumn{13}{|l|}{ Volume: } \\
\hline Total volume $\left[\mathrm{dam}^{3}\right]$ & 6247.4 & 34887.3 & 62613.3 & 6009.7 & 9142.4 & 21924.0 & 681672.4 & 49826.9 & 6827.0 & 8249.8 & 10682.2 & 75840.8 \\
\hline
\end{tabular}


The analysis of the trophic level of lakes was based on the Carlson method (1977), and on the rate of oxygen consumption (RAOD - relative areal oxygen deficit) in the hypolimnion during formation of the summer stratification, calculated using the method listed by Wetzel (2001) and Kalff (2022) introduced by Strøm (1931) and modified by Hutchinson (1938, 1957). Hydrochemical studies, i.e. regarding the total phosphorus and chlorophyll $a$ concentration, were conducted in accordance with the generally accepted methodology (APHA 1981, 1995).

The results obtained were analysed with the statistics program Statistica 9.0 (StatSoft, Inc. 2010) and are presented in the paper's tables.

\section{Results}

Under the Carlson system (1977), in assessing the trophic status of lake water the following elements are taken into consideration: measurements during the summertime of concentrations of total phosphorus and chlorophyll $a$ in the surface waters, and Secchi depth. The present chapter will discuss the values of these indicators found in the studied lakes in the years 1970-2010, and the trophic status indicators (TSI) calculated in accordance with the system applied.

Total phosphorus concentrations in surface waters of the lakes under consideration during the period of the study were on average 0.089 , with the range of variation from 0.030 to $0.222 \mathrm{mg} \mathrm{P} \mathrm{dm}^{-3}$. The lowest concentrations were below 0.051 , and the highest above $0.130 \mathrm{mg} \mathrm{P} \mathrm{dm}^{-3}$ (respectively, $10 \%$ of measurements in each of the ranges). The total phosphorus concentrations for the summertime in the surface waters of the lakes surveyed are shown in Table 2.

The lowest values of this indicator were measured in Lake Ińsko Duże: in most cases the concen- trations recorded were below $0.048 \mathrm{mg} \mathrm{P} \mathrm{dm}^{-3}$; they were higher only in the years 1982 and 1987 (0.068 $\mathrm{mg} \mathrm{P} \mathrm{dm}{ }^{-3}$ ). Lower concentrations of total phosphorus in comparison with other reservoir studies were found also in Lake Miedwie; usual values during summer stagnation in the surface waters were in the range of $0.055-0.060 \mathrm{mg} \mathrm{P} \mathrm{dm}^{-3}$. This range of concentrations resulted in the TSI calculated according to the Carlson model (1977) for these reservoirs attaining typically the levels from 55 to 60 , indicating that the waters of these lakes were in advanced stages of mesotrophy. Higher concentrations of phosphorus than those reported for Lakes Ińsko Duże and Miedwie have been measured in Lake Chłop Duży (range $0.050-0.070$ ) and on occasion, especially in the 1980s, in Lakes Krzemien and Morzycko. These phosphorus concentrations indicated a moderately low eutrophy level (TSI range of 60-65). The highest values of this particular indicator (above $0.100 \mathrm{mg} \mathrm{P} \mathrm{dm}^{-3}$ ) were recorded for Lakes Wądół, Będzin and Ińsko Małe, as well as Narost and Wisala reservoirs. The phosphorus concentration for these lakes, and the trophic status indicators calculated on their basis, clearly point to a considerable degree of advancement of the process of eutrophication (strong eutrophy).

The concentration of chlorophyll $a$ in the studied reservoirs varied within the range between 11.0 to $55.0 \mathrm{mg} \mathrm{m}^{-3}$, with an average concentration of $22.5 \mathrm{mg}$ $\mathrm{m}^{-3}$ for the years $1970-2010$; most often $(43.7 \%$ of the cases) the concentration stood between $20.0-25.0 \mathrm{mg}$ $\mathrm{m}^{-3}$ (Table 2).

The lowest concentrations of chlorophyll $a$ were recorded for the waters of Lake Ińsko Duże throughout the entire study period, and Lake Krzemien in the late 1970s and early 1980s; these concentrations stood at $15 \mathrm{mg} \mathrm{m}^{-3}$ and below. Similar values of this indicator were found for the most part also in the surface

Table 2. Selected statistical indicators of the concentrations of total phosphorus and chlorophyll-a in the surface waters of the studied lakes and Secchi depth during the summer stagnation

\begin{tabular}{|c|c|c|c|c|c|}
\hline Indicator & $\mathrm{N}$ & Average & Minimum & Maximum & Max. frequency range \\
\hline Total phosphorus & 140 & 0.089 & 0.030 & 0.222 & $0.080-0.100(26.6 \%)$ \\
\hline Chlorophyll a & 140 & 22.5 & 11.0 & 55.0 & $20.0-25.0(43.7 \%)$ \\
\hline Secchi depth & 140 & 1.97 & 0.40 & 4.30 & $1.0-2.0(39.2 \%)$ \\
\hline TSI-TP & 140 & 66.1 & 53.2 & 82.1 & $65.0-70.0(48.9 \%)$ \\
\hline TSI-Chl & 140 & 60.4 & 54.1 & 69.9 & $58.0-62.0(56.3 \%)$ \\
\hline TSI-SD & 140 & 51.6 & 39.0 & 73.2 & $45.0-55.0(58.3 \%)$ \\
\hline
\end{tabular}

TSI - trophic status indicators (scale 0-100);

Measurement units: total phosphorus $-\mathrm{mg} \mathrm{P} \mathrm{dm}^{-3}$, chlorophyll $a-\mathrm{mg} \mathrm{m}^{-3}$, Secchi depth $-\mathrm{m}$ 
waters of Lake Miedwie. In later years, the value of this indicator has significantly increased $\left(20 \mathrm{mg} \mathrm{m}^{-3}\right)$ in these two reservoirs. Slightly higher (16-20 $\left.\mathrm{mg} \mathrm{m}^{-3}\right)$ concentrations of chlorophyll $a$ were recorded for the waters of Lake Woświn. For the first three reservoirs listed above, the TSI value was typically 56-58, while for Lake Woświn it was 60, indicating, respectively, a highly advanced mesotrophy and the transition state between mesotrophy and eutrophy. Decidedly the highest $\left(>30 \mathrm{mg} \mathrm{m}^{-3}\right.$ ) chlorophyll a concentrations were measured in Lakes Będzin, Wądół, Ińsko Małe and Narost; slightly lower values $\left(>25 \mathrm{mg} \mathrm{m}^{-3}\right)$ were recorded in Lake Wisala. Such values of this indicator suggest an intensive ongoing process of eutrophication in these reservoirs, and a high level of eutrophy. The other lakes, taking into account the indicator being discussed, were characterized by average eutrophy levels (the concentration of chlorophyll $a$ in the range of 20-25 $\mathrm{mg} \mathrm{m}^{-3}$, and TSI 59-63).

Another determining indicator for the trophic level in the Carlson model (1977) is the Secchi disk visibility (Secchi depth). In the studied lakes, it varied during the study period from 0.4 to $4.3 \mathrm{~m}$, usually ranging between 1.0-2.0 $\mathrm{m}$ (Table 2). During the summer, the water transparency was the highest in Lake Ińsko Duże: for the whole period it was always above $2.8 \mathrm{~m}$, and at the end of the 1990s it ranged from 4.0 to $4.3 \mathrm{~m}$. These values were indicative of low value mesotrophy (TSI of 39-43). Water transparency of less than $1.0 \mathrm{~m}$ was recorded for Lakes Wądół, Będzin (TSI over 65) and less often also in Lake Narost; it clearly indicated the strong eutrophy of the waters of these reservoirs. In the other lakes, the indicator discussed was at the level characteristic for the waters on the borderline between mesotrophic and eutrophic, or for weak eutrophy.

In the studied lakes of Western Pomerania, the changes in the respective indicators characterizing each stage of the process of eutrophication were recorded during the study period. Lake Będzin, and in particular Lake Wądół were throughout the whole period strongly eutrophic. Lake Ińsko Duże on the other hand remained a mesotrophic reservoir, with its best water quality in the late 1990s, while in Lakes Morzycko and Woświn reduced water quality was observed during the 1990s. The other reservoirs in the entire study period were characterized by a similar stage of eutrophication. Based on the research conducted, these reservoirs can be divided into three groups:

- the first group, including Lakes Będzin, Wądół and Ińsko Małe, where an advanced process of eutrophication was recorded, the rate of oxygen consumption RAOD during the formation of the summer heterothermy was the highest $\left(>100 \mu \mathrm{g} \mathrm{dm}^{-3} \mathrm{~d}^{-1}\right)$ for these reservoirs (Table 3),

- the second group, with Lakes Narost, Chłop Mały and Wisala, with characteristics typical for eutrophy, and oxygen consumption rate RAOD from 75 to $96 \mu \mathrm{g} \mathrm{dm}^{-3} \mathrm{~d}^{-1}$ (Table 3 ),

- the third group, made up of Lakes Woświn, Morzycko, Miedwie, Krzemień, Chłop Duży and Jelenin, with systems typical for the borderline between mesotrophic and eutrophic (oxygen consumption rate of 49-64 $\mu \mathrm{g} \mathrm{dm}^{-3} \mathrm{~d}^{-1}$; Table 3). Outside of these groups remains Lake Ińsko, where the rate of oxygen consumption (Relative Areal Oxygen Deficit) was less than $40 \mu \mathrm{g} \mathrm{dm}^{-3} \mathrm{~d}^{-1}$ (Table 3 ).

\section{Discussion}

Lakes are dynamic ecosystems that change over time in order to enrich and intensify the biological production. Transport, exchange and redistribution of mineral matter, derived from biogeochemical processes, organic matter produced in the ecosystem and contaminants introduced into the environment are the processes determining the direction and rate of lake evolution (Gotkiewicz et al. 1990; Lossow and Więcławski 1991). In the local conditions, these processes are dependent on the whole set of factors: climatic, hydrological, hydrogeological and soil conditions in the catchment area. In addition, they are impacted by the morphometric characteristics and

Table 3. The rate of oxygen consumption (RAOD) in the hypolimnion waters in the studied lakes during the formation of the summer stagnation

\begin{tabular}{lcccccccccccccccc}
\hline RAOD I* & Będzin & $\begin{array}{c}\text { Chłop } \\
\text { Duży }\end{array}$ & $\begin{array}{c}\text { Chłop } \\
\text { Mały }\end{array}$ & $\begin{array}{c}\text { Ińsko } \\
\text { Duże }\end{array}$ & $\begin{array}{c}\text { Ińsko } \\
\text { Małe }\end{array}$ & Jelenin & Krzemień & Miedwie & Morzycko & Narost & Wądół Wisala Woświn \\
\hline$\mu \mathrm{dm}^{-3} \mathrm{~d}^{-1}$ & 137.2 & 49.0 & 75.0 & 31.7 & 106.9 & 63.0 & 50.1 & 43.5 & 63.7 & 83.4 & 149.0 & 96.6 & 63.7 \\
$\mathrm{mg} \mathrm{cm}^{-2} \mathrm{~d}^{-1}$ & 0.053 & 0.044 & 0.048 & 0.040 & 0.051 & 0.045 & 0.046 & 0.043 & 0.046 & 0.049 & 0.057 & 0.046 & 0.045 \\
\hline
\end{tabular}

॥* - Relative areal oxygen deficit (Strøm 1931, Hutchinson 1938, 1957) 
hydrochemical relations of the reservoir (Olszewski and Tadajewski 1959; Lossow 1996; Stumm and Morgan 1996; Kalff 2002). Of key importance to the lake are also the dynamics of water masses (Patalas 1960), the functioning of its biocenosis, and exchange of elements between the solid phase and solution (Olszewski and Tadajewski 1959; Stumm and Morgan 1996; Kalff 2002). These factors determine the intensity of lakes' eutrophication process (Table 4).

In the waters of Lakes Wądół and Będzin, the characteristics indicating a very high trophic level were observed through the whole study period, which was primarily due to their high susceptibility to degradation (Kubiak 2003). This was reinforced by the tachymictic type of water mass mixing, their shallowness, developed coastline and the small volume of the lake basin (Kubiak and Tórz 2005, 2006). Lake Będzin's catchment area was intensively cultivated. Other parameters which characterize the area's susceptibility to degradation were also adverse: it is a flow-through lake, and a reservoir of this type is subject to high loading of matter from the outside, and is therefore particularly at risk of eutrophication (Hillbricht-Ilkowska and Kostrzewska-Szlakowska 1996).
In the case of Lake Wądól, the catchment area is a highly urbanized area, and the reservoir was used for recreational purposes, and for a number of years it was also a collector of municipal wastewater. In both of these lakes, the unfavourable ratio of the volume of the lake basin to the length of the developed shoreline caused the pollution load flowing from the catchment area to be received by a small volume of water. Such natural conditions resulted in poor water quality, and the eutrophication of lakes occurred at a rapid pace (Kubiak 2003).

Lakes Chłop Mały, Ińsko Małe, Wisala and Narost according to the Carlson criteria (1977) were eutrophic throughout the whole study duration. They were characterized by a tachymictic (Chłop Mały, Ińsko Małe, Wisala) or eumictic, with inclination to tachymictic (Narost) water mass mixing (Kubiak and Tórz 2005, 2006).

In these lakes, a major part of the lake bottom in the summer remained in the range of warm epilimnion, resulting in rapid recirculation of nutrients from bottom sediments into the water. The natural characteristics of the catchment area favoured surface runoff, (eg. lack of area), and therefore the pressure on the

Table 4. Mean values of trophic levels after Carlson (1977) in the waters of the lakes surveyed in the studied period

\begin{tabular}{|c|c|c|c|c|c|c|c|c|c|c|c|c|c|}
\hline Indicator & Będzin & Chłop D & Chłop M & Ińsko M & Ińsko D & Jelenin & Krzemień & Miedwie & Morzycko & Narost & Wądół & Wisala & Woświn \\
\hline $\begin{array}{l}\% \mathrm{O}_{2} \text { - summer; } \\
\text { bottom }\end{array}$ & 0.4 & 19.3 & 6.5 & 6.7 & 36.6 & 6.8 & 7.2 & 14.1 & 7.0 & 4.5 & 0.0 & 0.1 & 6.0 \\
\hline $\begin{array}{l}\text { TN - summer; } \\
\text { surface }\end{array}$ & 2.372 & 1.612 & 1.751 & 2.436 & 1.834 & 1.819 & 1.395 & 0.736 & 1.753 & 1.777 & 3.591 & 1.728 & 2.156 \\
\hline $\begin{array}{l}\text { TP - summer; } \\
\text { surface }\end{array}$ & 0.111 & 0.061 & 0.093 & 0.103 & 0.048 & 0.083 & 0.080 & 0.048 & 0.083 & 0.097 & 0.407 & 0.095 & 0.077 \\
\hline TP - average & 0.121 & 0.067 & 0.082 & 0.081 & 0.039 & 0.056 & 0.100 & 0.075 & 0.071 & 0.066 & 0.258 & 0.072 & 0.091 \\
\hline TN/TP & 20.2 & 26.7 & 19.6 & 25.5 & 40.1 & 22.4 & 18.2 & 37.3 & 22.5 & 18.3 & 9.7 & 18.1 & 28.3 \\
\hline Chl a-summer & 33.0 & 19.6 & 25.2 & 31.7 & 17.6 & 19.2 & 16.0 & 11.0 & 20.3 & 27.3 & 46.6 & 23.4 & 19.1 \\
\hline Chl a-spring & 15.5 & 10.6 & 13.8 & 12.4 & 11.3 & 11.8 & 7.6 & 5.0 & 8.8 & 11.4 & 26.6 & 9.8 & 11.7 \\
\hline Chl a-average & 24.2 & 14.5 & 19.6 & 21.8 & 14.5 & 15.6 & 12.0 & 10.0 & 14.6 & 19.4 & 34.1 & 17.0 & 15.4 \\
\hline SD - summer & 0.6 & 2.3 & 1.8 & 1.4 & 3.7 & 2.6 & 2.2 & 2.8 & 2.4 & 1.3 & 0.6 & 1.6 & 2.2 \\
\hline SD - spring & 1.7 & 2.8 & 2.4 & 2.3 & 4.7 & 4.2 & 3.2 & 3.4 & 3.2 & 2.0 & 1.1 & 2.3 & 3.3 \\
\hline $\mathrm{SD}$ - average & 1.1 & 2.6 & 2.1 & 1.8 & 4.2 & 3.4 & 2.7 & 3.0 & 2.7 & 1.6 & 0.9 & 2.2 & 2.8 \\
\hline \multirow{2}{*}{ TSI-SD (summer) } & 68 & 48 & 52 & 55 & 41 & 46 & 49 & 45 & 48 & 57 & 66 & 53 & 48 \\
\hline & EU & ME & ME & ME & ME & ME & ME & ME & ME & ME & EU & ME & ME \\
\hline \multirow{2}{*}{ TSI-Chl (summer) } & 65 & 60 & 62 & 64 & 59 & 60 & 58 & 54 & 60 & 63 & 68 & 62 & 59 \\
\hline & EU & ME & EU & EU & ME & ME & ME & ME & EU & EU & EU & EU & ME \\
\hline \multirow{2}{*}{ TSI-TP (summer) } & 72 & 63 & 70 & 71 & 60 & 68 & 67 & 60 & 68 & 70 & 91 & 70 & 67 \\
\hline & EU & EU & EU & EU & ME & EU & EU & ME & EU & EU & EU & EU & EU \\
\hline
\end{tabular}

$\mathrm{SD}$ - Secchi depth, Chl $a$ - chlorophyll concentration, TP - total phosphorus concentration, $\mathrm{TN}$ - total nitrogen concentration, $\% \mathrm{O}_{2}-\mathrm{oxy}_{-}$ genation level, ME - mesoeutrophy, EU - eutrophy 
lakes was large, resulting in their rapid eutrophication (Bajkiewicz-Grabowska 1990; Kudelska et al. 1994). In addition, intense eutrophication of these reservoirs was further reinforced by the usage of the catchment area, with a substantial share of farmland. Furthermore, the eutrophication has been intensified as a result of unfavourable morphological conditions of the lake basin (small basin volume with considerable length of coastline, thus the load of pollutants flowing from the catchment area was collected by a small volume of water).

Lakes with borderline meso-and eutrophic characteristics throughout the study were Lakes Chłop Duży, Morzycko, Jelenin, Krzemień and Woświn; only in Lake Morzycko did the eutrophic characteristics prevail over the mesotrophic. All these reservoirs were medium-resistant to degradation, except for the highly resistant Lake Morzycko (Kubiak 2003; Kubiak and Tórz 2004). The catchment area conditions in which the catchment area was little or moderately susceptible to loading of biogenic matter stored in its area caused the variations in the rate of eutrophication: slow for Lakes Jelenin and Chłop; moderate in Lakes Morzycko, Krzemień and Woświn (Kubiak 2003). The slower pace of eutrophication was due to the agricultural and forest character of the immediate catchment area, reducing its capacity for loading of biogenic matter accumulated in the area. The favourable conditions of the catchment area resulted in meso-eutrophy of Lakes Chłop Duży and Jelenin. On the other hand, in the case of Lakes Krzemien and Woświn this state of affairs (despite the adverse conditions in the catchment area) was the result of the lake basin features such as greater lake depth and volume. The tendency of Lake Chłop Duży to bradymictic mixing of water masses, with high resistance to degradation and low catchment area susceptibility to biogene loading, meant that the advancement of the eutrophication process in the reservoir was the lowest among the meso-eutrophic lakes.

The mesotrophic Lake Ińsko Duże had medium or high resistance to degradation; this was favoured by the lake's significant depth, eumictic - with inclination to bradymictic - water mass mixing type and a significant share of hypolimnion in the total volume of the lake (Kubiak 2003). The small surface of the lake bottom within the epilimnion has reduced the intensity of the recirculation of biogenic elements from the sediment layer to the trophogenic layer. High resistance to degradation balanced out the unfavourable lake catchment area conditions. The catchment area with a prevalence of farmland and forest and some buildings took part in its entirety in the delivery of biogenic loads to the lake; it showed, however, only average loading of the matter deposited in the catchment area (Bajkiewicz-Grabowska 1990). The rate of eutrophication of the lake was moderate (Kubiak 2003).

The assessment of the trophic level of Lake Miedwie according to the Carlson criteria (1977) has shown that it is currently a mesotrophic reservoir with elevated concentrations of phosphorus (typical for eutrophy). Earlier, in the 1990s, it was a eutrophic water body. The studies conducted showed that the reservoirs less resistant to anthropopressure, with catchment areas favourable to surface runoff, had the trophic level high enough that it was impossible to determine significant trophic level fluctuations in them. On the other hand, the highly degradation resistant lakes did not show such trends, as they were effectively protected from the impact from the outside thanks to their natural features. It was also found that the reservoirs studied had varied trophic levels; the lakes with lower trophic status (Ińsko Duże, Chłop Duży, Jelenin) had, during the summertime, lower water dynamics and a more marked stratification of water masses. This has caused a limited penetration of biogenic elements from the hypolimnion to the euphotic layer (Patalas 1960; Kalff 2002).

\section{References}

[APHA] American Public Health Association, 1981, Standard Methods for the examination of water and wastewater, Amm. Publ. Health Ass. Inc., New York, p. 1966.

[APHA] American Public Health Association, 1995, Standard methods for the examination of water and waste water, Amm. Publ. Health Ass., New York, p. 1956.

Bajkiewicz-Grabowska E., 1990, Stopień naturalnej podatności jezior na eutrofizację na przykładzie wybranych jezior Polski (Degree of natural susceptibility to eutrophication of lakes, based on selected Polish lakes), Gospod. Wod. 12: 270-272 (in Polish).

Carlson R.F., 1977, A trophic state index for lakes, Limnol. Oceanogr. 22(2): 361-369.

Choiński A., Ptak M., 2009, Lake Infill as the Main Factor Leading to Lake's Disappearance, Polish J. of Environ. Stud. 18 (3): 347-352.

Gotkiewicz J., Hutorowicz H., Lossow K., Mosiej J., Pawłat H., Szymczak T., Traczyk T., 1990, Czynniki kształtujące obieg wody i biogenów w krajobrazie młodoglacialnym (Factors affecting the circulation of water and nutrients in the postglacial landscape), [in:] Ryszkowski L. Marcinek K., Kędziora A. (eds), Obieg wody i bariery bio- 
geochemiczne w krajobrazie rolniczym (The water cycle and biogeochemical barriers in agricultural landscape), Wyd. Nauk. UAM, Poznań: 105-126 (in Polish).

Hillbricht-Ilkowska A., 1998, Różnorodność biologiczna siedlisk słodkowodnych - problemy, potrzeby, działania (Biological diversity of freshwater habitats - problems, needs, activities), Idee Ekol. Ser. Szkice 13(7): 13-55 (in Polish).

Hillbricht-Ilkowska A., Kostrzewska-Szlakowska I., 1996, Ocena ładunku fosforu i stanu zagrożenia jezior rzeki Krutyni (Pojezierze Mazurskie) oraz zależności pomiędzy ładunkiem a stężeniem fosforu w jeziorach (Phosphorus load rating and level of risk of lakes of the River Krutynia (Masurian Lakeland) and the relationship between the load and the concentration of phosphorus in lakes), Zesz. Nauk. Kom. Nauk „Człowiek i Środowisko” PAN 13: 97-123 (in Polish, English summary).

Hutchinson G.E., 1938, Chemical stratification and lake morphology, Proc. Nat. Acad. Sci. USA 24: 63-69.

Hutchinson G.E., 1957, A Treatise on Limnology. Vol I. Geography, Physics and Chemistry, Wiley, New York, p. 1015.

Kalff J., 2002, Limnology, Prentice Hall Ltd., New Jersey, p. 592.

Kubiak J., 2003, Największe dimiktyczne jeziora Pomorza Zachodniego. Stan trofii podatność na degradacje oraz warunki siedliskowe ichtiofauny ( The Largest dimictic Lakes of Western Pomerania: Trophic status, susceptibility to degradation, and habitat conditions for fish fauna), Rozprawy ARSzcz. 214, Szczecin, p. 96 (in Polish, English summary).

Kubiak J., Tórz A., 2004 , Variations In the trophic state of the mesotrophic Ińsko Duże Lake (1970-2002), Limnol. Rev. 4: 115-124.

Kubiak J., Tórz A., 2005, Water mass dynamics in the largest stratified lakes of western Pomerania in relation to their trophic status, Limnol. Rev. 5: 129-136.

Kubiak J., Tórz A., 2006, Thermal regime of the biggest dimictic lakes of Western Pomerania region, Limnol. Rev. 6: 155-162.

Kudelska D., Cydzik D., Soszka H., 1994, Wytyczne monitoringu podstawowego jezior (Guidelines for basic monitoring of lakes), PIOŚ, Warszawa, p. 42 (in Polish).
Lossow K., 1995, Odnowa jezior (Restoration of lakes), Ekoprofit. 5: 11-15 (in Polish).

Lossow K., 1996, Znaczenie jezior w krajobrazie młodoglacialnym pojezierza Mazurskiego (The importance of the lakes in the landscape of the Masurian Lake District), Zesz. Probl. Post. Nauk Rol. 431: 47-59 (in Polish).

Lossow K., Więcławski F., 1991, Migracja podstawowych pierwiastków pożywkowych z gleb, użytkowanych rolniczo do wód powierzchniowych (Migration of the basic elements of nutrients from soils used for agriculture to surface waters), Biul. Inf. ART Olszt. 31: 123-133 (in Polish).

[OBiKŚ] Ośrodek Badań i Kontroli Środowiska, 1977, Atlas czystości jezior województwa szczecińskiego 1970-1976 (Atlas of lake quality conditions in voivodship of Szczecin 1970-1976) [typescript], Szczecin (in Polish).

Olszewski P., Tadajewski A., 1959, Wpływ zlewni na żyzność jezior (Effects on fertility of basin lakes), Zesz. Nauk. WSR Olszt. 4: 191-194 (in Polish, English summary).

Patalas K., 1960, Mieszanie wiatrowe jako czynnik określający intensywność krążenia materii w różnych morfologicznie jeziorach okolic Węgorzewa (Mixing of wind as a factor determining the intensity of circulation of matter in morphologically different lakes surrounding Węgorzewo), Rocz. Nauk Rol. Ser. B 77(1): 224-241 (in Polish, English summary).

StatSoft , 2010, STATISTICA (data analysis software system), version 9.0.

Strøm K.M., 1931, Feforvatn: A physiographic and biological study of a mountain lake, Arch. Hydrobiol. 22: 491536.

Stumm W., Morgan J., 1996, Aquatic chemistry. Chemical equilibrium and rates in natural waters, Wiley, New York, p. 1022.

Vollenweider R.A., 1971, Scientific fundamentals of the eutrophication of lakes and following waters, with particular reference to nitrogen and phosphorous as factors in eutrophication, OECD, Paris, p. 61.

Vollenweider R.A., 1989, Global problems of eutrophication and its control, Symp. Biol. Hung. 38: 19-41.

Wetzel R. G., 2001, Limnology, W.B. Saunders Company, Philadelphia, p. 743. 